\title{
Retraction Note: A brief history of human evolution: challenging Darwin's claim
}

Sarah Umer

Received: 13 February 2019 / Accepted: 13 February 2019 / Published online: 19 February 2019 (C) The Author(s). 2019 Open Access This article is distributed under the terms of the Creative Commons Attribution 4.0 International License (http://creativecommons.org/licenses/by/4.0/), which permits unrestricted use, distribution, and reproduction in any medium, provided you give appropriate credit to the original author(s) and the source, provide a link to the Creative Commons license, and indicate if changes were made.

\section{Retraction Note: International Journal of Anthropology and Ethnology (2018) 2:6. https://doi.org/10.1186/s41257-018-0014-2}

The Editor-in-Chief has retracted this article (Umer, 2018), because it was published in error before the peer review process was completed. Further post publication peer review determined that the article is not suitable for publication in the International Journal of Anthropology and Ethnology. The author does not agree to this retraction.

\section{Reference}

Umer, A. 2018. A brief history of human evolution: challenging Darwin's claim. International Journal of Anthropology and Ethnology 2: 6 https://doi.org/10.1186/s41257-018-0014-2.

\footnotetext{
S. Umer $(\bowtie)$

Department of Visual Arts and Graphic Design, Institute of Visual Arts \& Design, Lahore College for Women University, Lahore, Pakistan e-mail: sarah76khan@gmail.com
} 